Case report

\title{
Chlorpromazine induced priapism from a single dose: an unusual complication of antipsychotic agent
}

\author{
Mohamed Ahmed Abd El Salam, Hisham Foaad \\ Cairo University, Cairo, Egypt
}

Received 20 March 2017, Accepted 4 April 2017

(C) 2017, Abd El Salam M.A., Foaad H.

(C) 2017, Russian Open Medical Journal

\begin{abstract}
Priapism is considered as an unusual andrological emergency that requires urgent intervention. It is defined as prolonged penile erection (usually painful) for more than 4 hours not related to sexual excitation or stimulation. Several causes have been attributed to cause such condition including the use of psychotropic drugs as chlorpromazine. Only few case reports in literature have recorded priapism as a complication of administration of chlorpromazine, however most of them were due to overdose or prolonged administration for prolonged period or as an interaction with other drugs. Here, in this case report is about a 23 years old male presented to the emergency department with neglected priapism after administration of a single dose of chlorpromazine.
\end{abstract}

Keywords: andrological emergency, antipsychotic, chlorpromazine, priapism, single dose

Cite as Abd El Salam MA, Foaad H. Chlorpromazine induced priapism from a single dose: an unusual complication of antipsychotic agent. Russian Open Medical Journal 2017; 6: e0306.

Correspondence to Mohamed Ahmed Abd El Salam. Email: moh_756@yahoo.com. Tel: +20-01002018226. Fax: +20-20223682030.

\section{Introduction}

Priapism is a rare pathological condition of prolonged penile erection that persists beyond 4 hours and not related to sexual stimulation. It is mainly classified into three main types: Ischaemic (low-flow or veno-occlusive) priapism, arterial (high flow or nonischaemic) priapism and stuttering (recurrent or intermittent) priapism [1].

Ischaemic priapism is the most common type of priapism (accounting for more than 95\% of cases) that is due to obstruction of venous outlows from leading to impaired perfusion of cavernous tissue with subsequent hypoxia, hypercapnia and acidosis ending in fibrosis and erectile dysfunction. Several causes have been attributed to cause ischemic priapism including hemoglobinopathies (including sickle cell anaemia), hypercoagulable status, neoplastic syndromes, compressive pelviabdominal masses and use of some recreational drugs and medications (intracavernosal injections of papaverine, phentolamine and prostaglandin E1 (PGE1), anticoagulants, alphablockers, antidepressants, antipsychotics). However, ischaemic priapism has been identified as idiopathic in the majority of cases since no specific cause could be identified. Early management of ischaemic priapism with aspiration/irrigation along with the use of sympathomimetic agents gives better outcome. However, if left untreated, resolution may take days and erectile dysfunction invariably results that may require penile prosthesis implantation [2].

Unlike the ischemic priapism, the non ischemic priapism usually results from penile or perineal trauma or surgery that causes laceration in the cavernosal, perineal or pudendal artery leading to a high-flow fistula between the artery and the lacunar spaces of the sinusoidal tissue. It is characterized by less rigid nonpainful penile erection and less damage of the erectile cavernous tissue. Management of such cases includes conservative therapy and angiography with embolization of the fistulous connections [3].

Finally, the stuttering priapism is characterized by recurrent attacks of priapism that usually resolve spontaneously. The etiology of stuttering priapism is similar to that of ischaemic priapism; however, sickle cell disease is the most common cause. The cause can also be idiopathic and rarely due to a neurological disorder. Interventions for this type of recurrent problem include aggressive blockade of testosterone with ketoconazole (which requires supplementation of corticosteroids to prevent adrenal insufficiency), anti-androgens and luteinizing hormone-releasing hormone (LHRH) agonists, low dose of phosphodiesterase type 5 (PDE5) inhibitors and self injections of sympathomimetics [4].

Chlorpromazine is a conventional antipsychotic which is commonly used for its sedative properties. Although peripheral alpha-1 blockade and central serotonin-like actions of this agent are known, dose, route of administration and intake duration causing priapism and the etiology are yet not clarified [5]. In this report, we present a case of neglected priapism that developed after the oral administration of a single dose of chlorpromazine which is considered as unusual side effect.

\section{Case Report}

A 23-year-old male patient who presented to the emergency department in our hospital complaining of prolonged penile erection for more than 72 hours after he took a single dose of two tablets of chlorpromazine (tab. Neurazine ${ }^{\circledR} 100$ mg, Product of 
Misr Co. for Pharm. Ind. S.A.E), due to insomnia. He gave a history of previous attempts of aspiration/irrigation along with sympathomimetics in another hospital that failed, upon which they referred him to our hospital as a tertiary care center.

On clinical examination the vital signs were normal but the penis was fully erect, tender, and edematous with ecchymotic patches from the previous attempt of evacuation. Blood gas analysis of the cavernosal blood was analyzed and showed hypoxia, hypercapnia and acidosis. Additionaly, penile duplex examination showed absence of blood flow in both cavernosal arteries. All the above findings denoted a case of veno-occlusive (ischemic/low flow) priapism.

The patient was then admitted for investigating to rule out other cause of priapism; where $\mathrm{CBC}$ with differential, toxicology screening, $\mathrm{Hb}$ electrophoresis, coagulation profile, pelvi-abdominal US, semen and urine cultures were done and all of them were normal.

Finally, the patient was operated upon for urgent penile prosthesis implantation (to avoid extensive cavernosal fibrosis and easy placement of the implant and postoperative follow up visits in the outpatient clinic were uneventful.

\section{Discussion}

Priapism is an important andrological emergency. Early intervention is so crucial to save the erectile cavernous tissue thus preserving the erectile function of the penis. Although priapism resulting from antipsychotic drugs is not seen often and few cases were reported, however this is an important condition.

Antipsychotic drugs including thiothexene, chlorpromazine, thioridazine and risperidone have been reported as a causative factor of priapism. Most of the studies refer priapism to their peripheral alpha-1 blockade and central serotonin-like actions. However, the exact etiopathological mechanism by which they cause priapism is still not clarified [5].

Concerning priapism induced by chlorpromazine, just few reported cases have been mentioned in literature and most of them were due to overdose, long term therapy of psychiatric illness [6] or interaction as well as Combined use of antipsychotics, psychostimulants, antidepressants, and mood stabilizers as Risperidone, quetiapine, methylphenidate and trazadone [7]. In addition, only one case reported priapism after self administered chlorpromazinte via transuretheral route [8].

In addition, only few case reports have discussed that priapism occurred after a short-term administration of chlorpromazine as our case report that was unusual presentation $[9,10]$.

\section{Conclusion}

Recently, a number of priapism cases have increased depending on antipsycotic drug intake. Thus, physicians must be alert and oriented about this condition. In addition, early diagnosis and proper, rapid management of such cases could lead to favorable prognosis and better outcome.

\section{Conflict of interest}

No conflict of interest to be declared.

\section{References}

1. Broderick G, Kadioglu A, Bivalacqua T, Ghanem H, Nehra A, Shamloul R. Priapism: pathogenesis, epidemiology, and management. J Sex Med 2010; 7(1): 476-500. https://doi.org/10.1111/j.1743-6109.2009.01625.x.

2. El-Bahnasawy M, Dawood A, Farouk A. Low-flow priapism: risk factors for erectile dysfunction. BJU Int 2002; 89(3): 285-290. https://dx.doi.org/10.1046/j.1464-4096.2001.01510.x.

3. Hatzichristou D, Salpiggidis G, Hatzimouratidis K, Apostolidis A, Tzortzis V, Bekos A, Saripoulos D. Management strategy for arterial priapism: therapeutic dilemmas. J Urol 2002; 168(5): 2074-2077. https://doi.org/10.1097/01.ju.0000032743.39599.ae.

4. Morrison BF, Burnett AL. Stuttering priapism: insights into pathogenesis and management. Curr Urol Rep 2012; 13(4): 268-276. https://doi.org/10.1007/s11934-012-0258-9.

5. Sinkeviciute I, Kroken RA, Johnsen E. Priapism in antipsychotic drug use: a rare but important side effect. Case Rep Psychiatry 2012; 2012 : 496364. https://doi.org/10.1155/2012/496364.

6. Kilciler M, Bedir S, Sümer F, Dayanç M, Peker A. Priapism in a patient receiving long-term chlorpromazine therapy. Urol Int 2003; 71(1): 127128. https://doi.org/10.1159/000071112.

7. Baytunca M, Kose S, Ozbaran B, Erermis S. Risperidone, quetiapine and chlorpromazine may have induced priapism in an adolescent. Pediatr Int 2015; 58(1): 61-63. https://doi.org/10.1111/ped.12741.

8. Jackson $\mathrm{S}$, Walker J. Self-administered intraurethral chlorpromazine: An unusual cause of priapism. Am J Emerg Med 1991; 9(2): 171-175. https://www.ncbi.nlm.nih.gov/pubmed/1994948.

9. Turkan S, Kalkan M, Şahin C. Two priapism cases following short-term use of chlorpromazine. J Clin Anal Med 2014; 5(1):47-48. https://doi.org/10.4328/JCAM.2710.

10. Suleekwe E. Priapism after a singular dose of chlorpromazine. Ann Biomed Sci 2011; 10(1). http://dx.doi.org/10.4314/abs.v10i1.69197.

\section{Authors:}

Mohamed Ahmed Abd El Salam - Lecturer, Department of Andrology, Sexology and STDs, Faculty of Medicine, Cairo University, Cairo, Egypt. http://orcid.org/0000-0002-7694-3852.

Hisham Foaad - Lecturer, Department of Andrology, Sexology and STDs, Faculty of Medicine, Cairo University, Cairo, Egypt. http://orcid.org/00000003-2775-3283. 